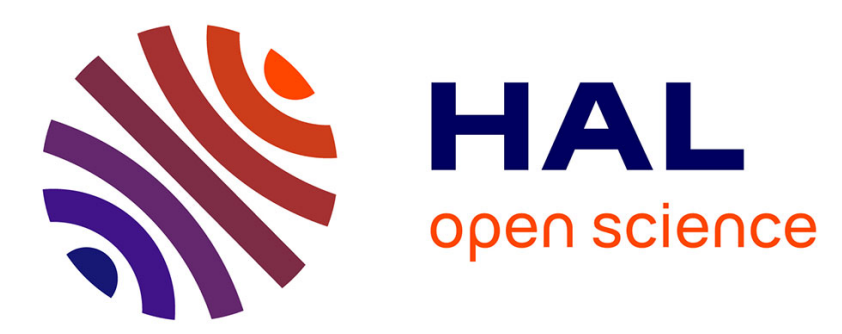

\title{
Helical Chirality Induces a Substrate-Selectivity Switch in Carbohydrates Recognitions
}

Augustin Long, Olivier Perraud, Muriel Albalat, Vincent Robert, Jean-Pierre Dutasta, Alexandre Martinez

\section{- To cite this version:}

Augustin Long, Olivier Perraud, Muriel Albalat, Vincent Robert, Jean-Pierre Dutasta, et al.. Helical Chirality Induces a Substrate-Selectivity Switch in Carbohydrates Recognitions. Journal of Organic Chemistry, 2018, 83 (12), pp.6301 - 6306. 10.1021/acs.joc.8b00276 . hal-01896109

\section{HAL Id: hal-01896109 https://hal.science/hal-01896109}

Submitted on 6 Apr 2019

HAL is a multi-disciplinary open access archive for the deposit and dissemination of scientific research documents, whether they are published or not. The documents may come from teaching and research institutions in France or abroad, or from public or private research centers.
L'archive ouverte pluridisciplinaire HAL, est destinée au dépôt et à la diffusion de documents scientifiques de niveau recherche, publiés ou non, émanant des établissements d'enseignement et de recherche français ou étrangers, des laboratoires publics ou privés. 


\title{
Helical Chirality Induces a Substrate-Selectivity Switch in Carbohydrates Recognitions
}

\author{
Augustin Long, $^{\dagger}$ Olivier Perraud, $^{\ddagger}$ Muriel Albalat, ${ }^{\dagger}$ Vincent Robert, $^{\S}$ Jean-Pierre Dutasta, ${ }^{\ddagger}$ \\ and Alexandre Martinez ${ }^{*}+\dagger$ \\ ${ }^{\dagger}$ Aix Marseille Univ, CNRS, Centrale Marseille, iSm2, Marseille F-13397, France \\ ${ }^{\ddagger}$ Laboratoire de Chimie, CNRS, École Normale Supérieure de Lyon, UCBL 46, Allée d'Italie, Lyon F-69364, France \\ ${ }^{\S}$ Laboratoire de Chimie Quantique Institut de Chimie, UMR CNRS 7177, Université de Strasbourg, 4, rue Blaise Pascal, Strasbourg \\ F-67070, France
}

\begin{abstract}
A new chiral hemicryptophane cage combining an electron-rich cyclotriveratrylene (CTV) unit and polar amine functions has been synthesized. The resolution of the racemic mixture has been performed by chiral HPLC, and the assignment of the absolute configuration of the two enantiomers has been achieved using ECD spectroscopy. In contrast with other hemicryptophane receptors, the two enantiomeric hosts display both remarkable enantioselectivities in the recognition of carbohydrates and good binding constants. Moreover, by switching the chirality of the CTV unit from $M$ to $P$, a strong preference shift from glucose to mannose derivatives is observed.
\end{abstract}

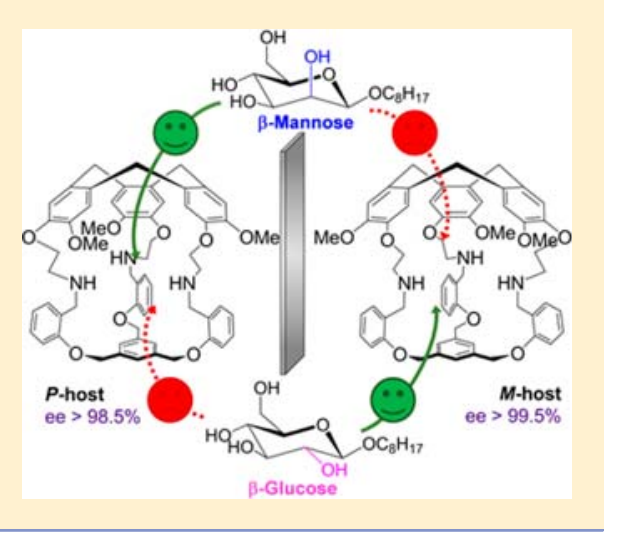

\section{INTRODUCTION}

The recognition of carbohydrates plays a crucial role in many biological processes, like tumor metastases, ${ }^{1}$ protein folding, ${ }^{2}$ infection by pathogens, ${ }^{3}$ or cell-cell recognition. ${ }^{4}$ Their chirality can account for their versatile use in living systems: sugars can be considered as the most information-rich biological molecules as they present numerous stereogenic centers. Thus, biological systems have developed selective receptors in order to exploit this structural variability. The selective recognition of carbohydrates by synthetic receptors through noncovalent interactions arouse a considerable interest as it could allow for a better understanding of these biological processes and lead to the establishment of new diagnostics or therapies in medicine. ${ }^{5-7}$ However, carbohydrate stereoisomers are very difficult to discriminate by synthetic hosts as they present complex three-dimensional structures, which often only differ by the configuration of a single stereogenic center. Cage receptors, when compared to their "open-shell" counterparts, appear particularly appealing because they can maximize the interactions with sugar guests in the heart of their cavity leading to a better selectivity. ${ }^{9}$ Among the cage compounds, hemicryptophanes have been recently described as a new class of receptors capable of complexing carbohydrates. ${ }^{10}$ These hosts, built from a cyclotriveratrylene (CTV) linked to another $C_{3}$ symmetrical moiety, display low to good binding constants and selectivities toward sugar guests. However, this class of host suffers from a major drawback in carbohydrate recognition: either hemicryptophanes display good binding constants but a low selectivity or a high selectivity is reached but associated with a modest affinity. For instance, host 1 exhibits good binding constants toward mannose up to $10^{3} \mathrm{M}^{-1}$, but negligible enantioselectivity is observed (binding constants are 1410 and $1544 \mathrm{M}^{-1}$ for the recognition of Oct- $\alpha$-Man with M-SSS-1 and P-RRR-1, respectively, Figure 1), ${ }^{11}$ whereas host 2 shows an exclusive enantioselectivity toward the Oct- $\alpha$-Glc derivative, but a much modest association constant of around $155 \mathrm{M}^{-1}$ is measured with the M-SSS enantiomer. ${ }^{12}$ Thus, there is a challenge to design new hemicryptophane cages capable of combining both good affinity and selectivity toward carbohydrates. Here we report on the synthesis of the enantiopure hemicryptophanes (-)-3 and (+)-3. Resolution of the racemic mixture has been achieved by chiral HPLC and assignment of their absolute configuration by electronic circular dichroism (ECD). Their recognition properties toward mannose, glucose and galactose derivatives reveal that both good binding constants (up to $10^{3} \mathrm{M}^{-1}$ ) and enantioselectivity (>99.5/0.5) can be achieved with host 3 . Interestingly, the change in the helical chirality of the CTV unit induces a substrate-selectivity switch: the $M-(-)-3$ enantiomer shows a better binding constant toward the $\beta$-glucose derivative, whereas the $P-(+)-3$ enantiomer exhibits a remarkable selectivity for mannose. 

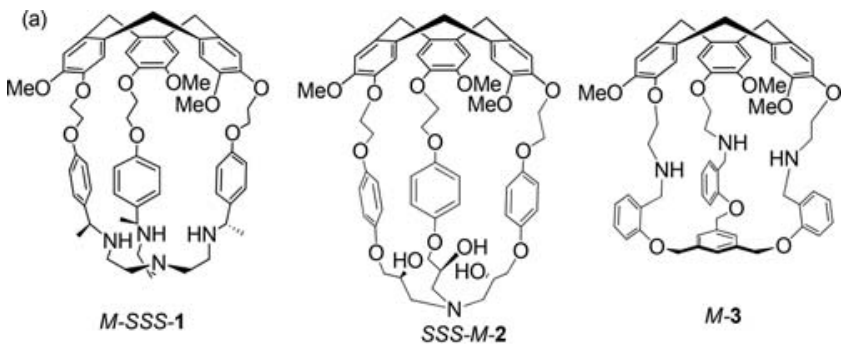

(b)
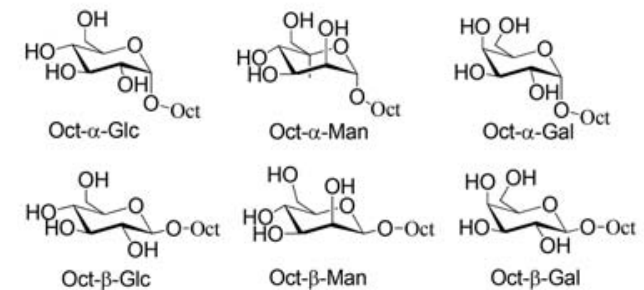

Figure 1. (a) Structures of hemicryptohane hosts 1-3. (b) Structures of the carbohydrate guests.

\section{RESULTS AND DISCUSSION}

Synthesis. Scheme 1 shows the synthetic pathway followed to synthesize the hemicryptophane rac-3. Cyclotriveratrylene derivative $\mathbf{4}$ was obtained according to the previously reported two-step procedure: vanillyl alcohol first reacts with 1,2dibromoethane, and the subsequent cyclization achieved with scandium triflate in $\mathrm{CH}_{3} \mathrm{CN}$ provides the $\mathrm{CTV}$ rac- 4 in an $18 \%$ overall yield. ${ }^{13}$ The reaction between sodium azide and rac-4 affords rac-5 in $90 \%$ yield. The reduction of the azido groups of rac-5 is performed with $\mathrm{PPh}_{3}$ in a mixture of THF and water at room temperature to give rac-6 in $91 \%$ yield. The $C_{3}$ symmetrical derivative 7 is obtained by the reaction between 1,3,5-tribromomethyl-benzene and 2-hydroxybenzaldehyde with $\mathrm{NaOH}$ in EtOH. Reductive amination between 7 and rac-6 is then achieved in a $\mathrm{CHCl}_{3} / \mathrm{MeOH}$ mixture providing rac-3 in a $42 \%$ yield. Thus, hemicryptophane rac- 3 was obtained with a six-step convergent synthesis, starting from the commercially available vanillyl alcohol with an overall yield of $6 \%$.

The resolution of the racemic mixture of hemicryptophane 3 is performed using chiral HPLC. The enantiomers are separated on an analytical Chiralpak ID $(250 \mathrm{~mm} \times 4.6 \mathrm{~mm})$ column with a resolution higher than two (Table S1). The use of a semipreparative Chiralpak ID $(250 \mathrm{~mm} \times 10 \mathrm{~mm})$ column with $\mathrm{EtOH}$ and $\mathrm{Et}_{3} \mathrm{~N} / \mathrm{CH}_{2} \mathrm{Cl}_{2}(50 / 50)$ as an eluent affords the $(-)$-enantiomer and (+)-enantiomer with ee $>99.5 \%$ and 98.5\%, respectively (Figures S16 and S17).

The hemicryptophanes (-)-3 and (+)-3 are on average of $C_{3}$ symmetry in solution as indicated by their ${ }^{1} \mathrm{H}$ NMR spectra in $\mathrm{CDCl}_{3}$. That of (+)-3 is shown in Figure 2 and displays the expected signals for the CTV moiety: the characteristic $A B$ system for the $\mathrm{ArCH}_{2}$ bridges at 3.53 and $4.73 \mathrm{ppm}$, two singlets for the aromatic protons at 6.90 and $6.75 \mathrm{ppm}$, and one singlet for the OMe group. The aromatic protons of the benzene ring in the lower part of the host appear as a singlet at $6.82 \mathrm{ppm}$, and the connected diastereotopic methylene bridges appear as two multiplets between 4.20 and $4.35 \mathrm{ppm}$. The signals of the aromatic protons of the linkers give two doublets and two triplets between 6.5 and $7.2 \mathrm{ppm}$, whereas the diastereotopic aliphatic protons exhibit expected broad multiplets.

Assignment of the Absolute Configuration. The ECD spectra of hosts $P-3$ and $M-3$ were recorded in $\mathrm{CH}_{2} \mathrm{Cl}_{2}$ at $298 \mathrm{~K}$ (Figure 3). Each spectrum exhibits the expected behavior for hemicryptophanes and CTV based host compounds, namely, two exciton patterns roughly centered on the isotropic absorption of the ${ }^{1} L_{\mathrm{B}}(290 \mathrm{~nm})$ and ${ }^{1} L_{\mathrm{A}}(240 \mathrm{~nm})$ transitions. As the signs of the ECD spectra in the ${ }^{1} L_{A}$ transition area are poorly sensitive to the nature of the substituents, the assignment of the absolute configuration of CTV's is usually performed by comparison to the calculated ECD spectra of a reference CTV, previously obtained by Collet and coworkers. ${ }^{14}$ Based on these previous works, the first (respectively second) eluted compound (+)-3 (respectively, (-)-3) corresponds to the $P$ configuration (respectively, $M$ configuration).

Recognition Properties. The inner cavity of hemicryptophane 3 presents both apolar (north and south parts) and polar domains ( $\mathrm{NH}$ groups in the linkers) and thus should provide appropriate matches for sugars complexation through $\mathrm{C}-\mathrm{H} \cdots \pi$ interactions and hydrogen bonding, respectively. Additions of a solution of Oct- $\beta$-Glc in $\mathrm{CDCl}_{3}$ to a solution of the enantiomer (-)-3 in the same solvent induce changes in the chemical shift of the ${ }^{1} \mathrm{H}$ signals of the cage, evidencing interactions between the sugar guest and the hemicryptophane host. The formation of a host-guest complex is also supported by mass spectrometry: a peak with an exact mass corresponding to the 1:1 host/guest ratio was detected in a mixture of (-)-3

Scheme 1. Synthesis of rac- $3^{a}$

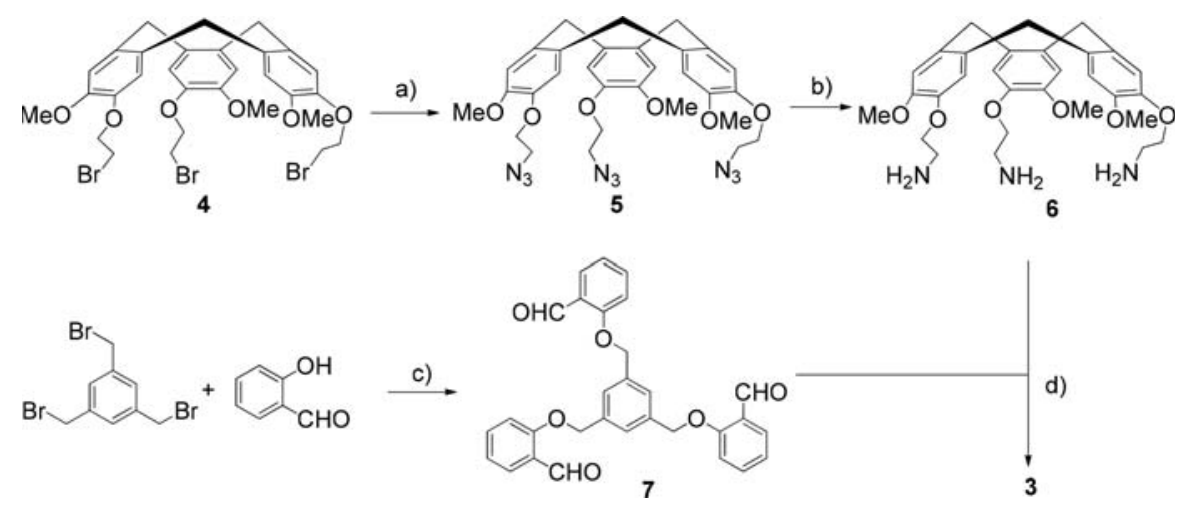

${ }^{a}$ Reaction conditions: (a) $\mathrm{NaN}_{3}, \mathrm{DMF}, 60^{\circ} \mathrm{C}, 16 \mathrm{~h}, 90 \%$; (b) $\mathrm{PPh}_{3}, \mathrm{THF} / \mathrm{H}_{2} \mathrm{O}$ (30/1), rt, 16 h, 91\%; (c) NaOH, EtOH, reflux, 20 h, 78\%; (d) (i) $\mathrm{CHCl}_{3} / \mathrm{MeOH}(1 / 1)$, rt, $18 \mathrm{~h}$, (ii) $\mathrm{NaBH}_{4}, 0^{\circ} \mathrm{C}$ to rt; $3 \mathrm{~h}, 42 \%$. 


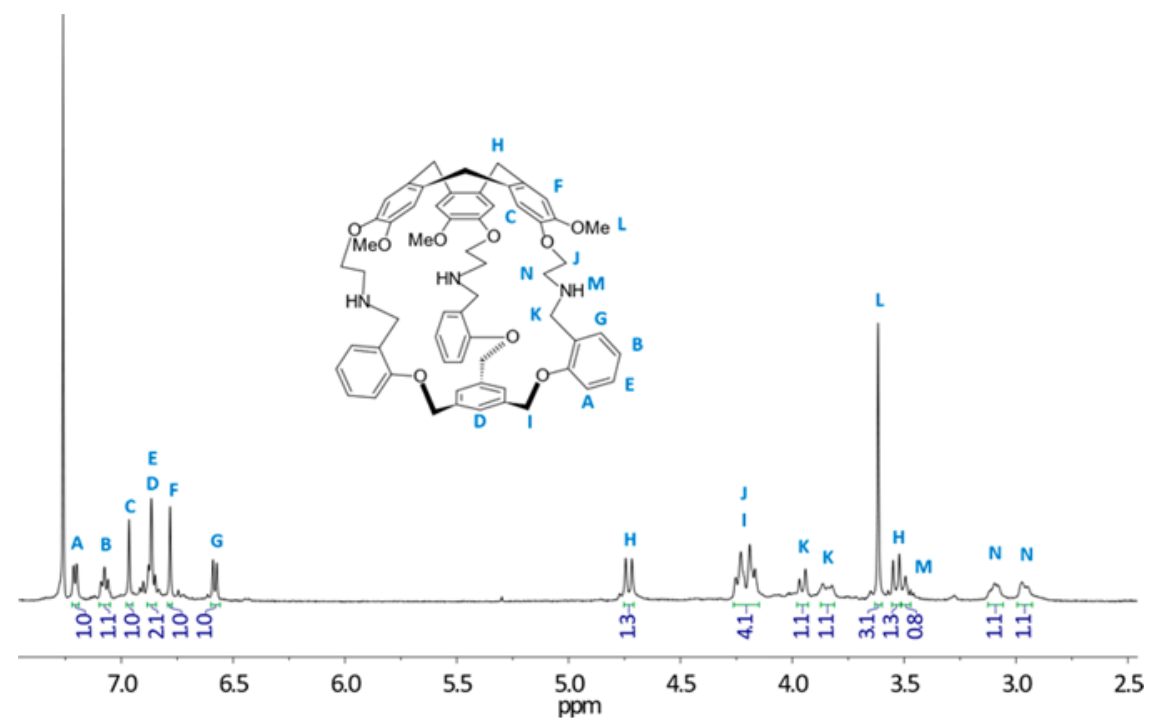

Figure 2. ${ }^{1} \mathrm{H}$ NMR spectra $\left(400 \mathrm{MHz}, \mathrm{CDCl}_{3}\right)$ of $(+)-3$.

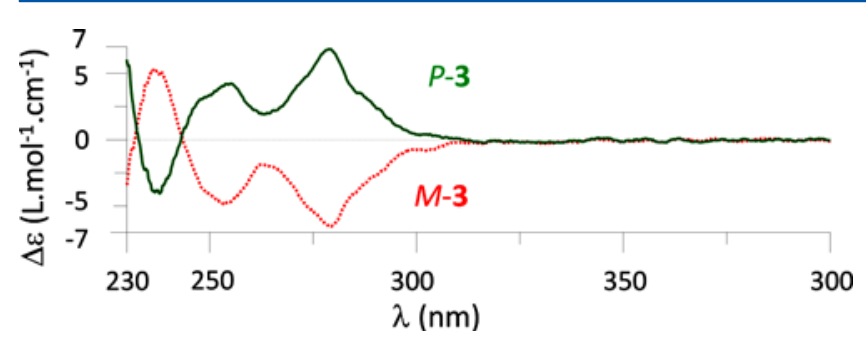

Figure 3. Experimental ECD spectra of the enantiomers of 3: the first eluted enantiomer is represented with a green solid line $(0.404 \mathrm{mmol}$ $\mathrm{L}^{-1}$ in $\left.\mathrm{CH}_{2} \mathrm{Cl}_{2}\right)$ and the second one by a red dotted line $(0.442 \mathrm{mmol}$ $\mathrm{L}^{-1}$ in $\mathrm{CH}_{2} \mathrm{Cl}_{2}$ ).

and Oct- $\beta$-Glc (Figure S20). Insights into the positioning of the carbohydrate inside the cavity of the hemicryptophane (-)-3 can be retrieved from the NOESY experiments performed on an equimolar solution of Oct- $\beta$-Glc and (-)-3. ${ }^{15,16}$ Although several signals overlap, precluding the assignment of the whole intermolecular contacts, the following intermolecular host/ guest NOEs contacts are unambiguously evidenced in the NOESY map: $\mathrm{OMe} / \mathrm{H}_{1}$ and $\mathrm{CTV}-\mathrm{H}_{\mathrm{ar}} / \mathrm{H}_{3}$ (Figure 4). These data strongly support the formation of an inclusion complex of Oct- $\beta$-Glc inside the cavity of (-)-3. It can be underlined that with other hemicryptophane derivatives, previously reported as receptors for carbohydrates, NOEs were never observed, suggesting that this Oct- $\beta$-Glc@(-)-3 complex is kinetically more stable in solution than the previously reported hemicryptophane complexes, although the host-guest exchange remains fast on the NMR time scale. ${ }^{9-12,17}$ Based on these intermolecular NOEs contacts, DFT calculations were then performed in order to provide a three-dimensional structure of the complex. The resulting minimized structure is shown in Figure 5 and is in agreement with the NOE experimental data $\left(\mathrm{H}_{1} \cdots \mathrm{OMe}\right.$ and $\mathrm{H}_{3} \cdots \mathrm{CTV}-\mathrm{H}_{\mathrm{ar}}$ distances of 2.5 and $3.9 \AA$, respectively). Furthermore, the optimized geometry of the (a)

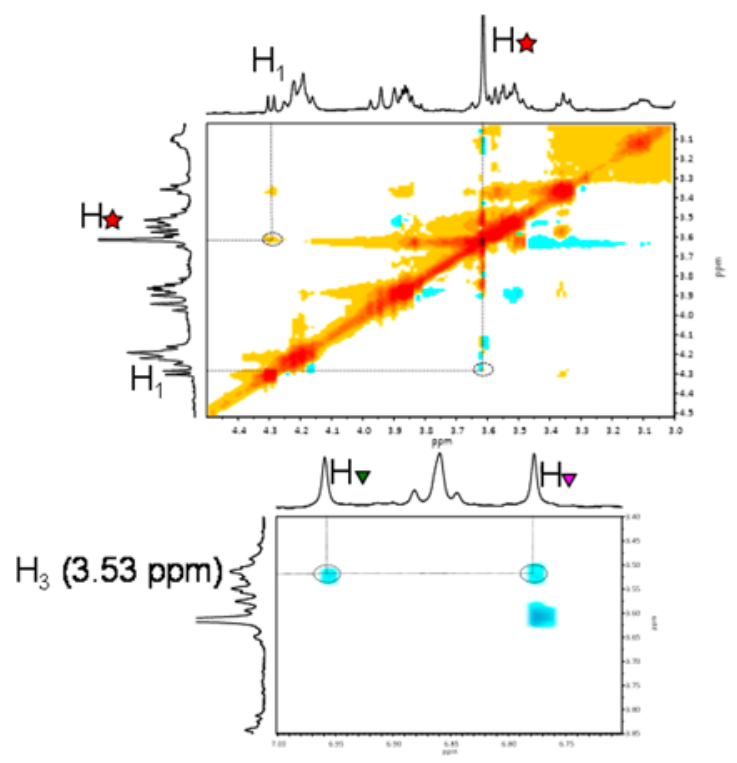

(b)

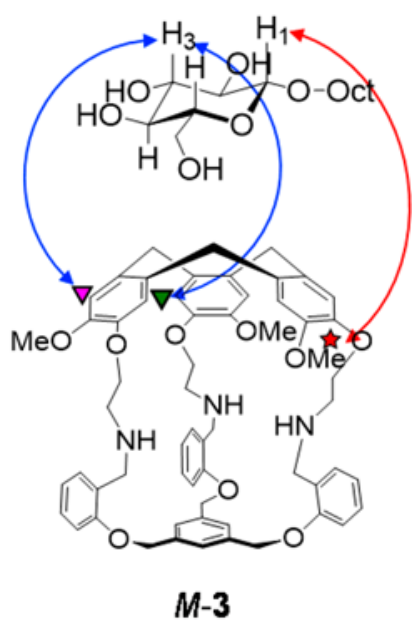

Figure 4. (a) $400 \mathrm{MHz}$ NOESY spectrum of a $1: 1$ mixture of Oct- $\beta$-Glc and (-)-3 in $\mathrm{CDCl}_{3}$ at $298 \mathrm{~K}$, acquired with a $500 \mathrm{~ms}$ mixing time. (b) Schematic representation of NOE contacts. 


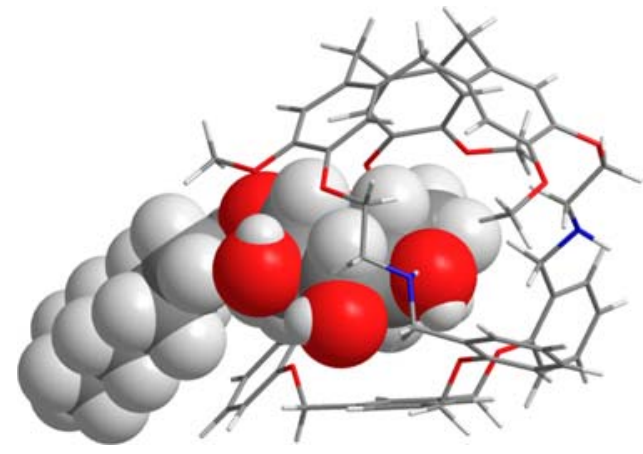

Figure 5. DFT optimized structure showing the encapsulation of Oct$\beta$-Glc guest within hemicryptophane (-)-3.

complex reveals that Oct- $\beta$-Glc is partially encaged in the hemicryptophane structure with the sugar unit trapped inside the cavity and the alkyl chain left outside. Hydrogen bonding between the alcohol functions of the guest and the nitrogen of the host 3 are observed. (For instance, $\mathrm{NH} \cdots \mathrm{O}_{4}$ and $\mathrm{NH} \cdots \mathrm{O}_{1}$ distances of 2.68 and $2.65 \AA$ are measured, respectively.) $\mathrm{CH} \cdots \pi$ interactions are also evidenced in the DFT structure with $\mathrm{H}_{1} \cdots \mathrm{CTV}-\mathrm{C}$ and $\mathrm{H}_{4} \cdots \mathrm{C}-\mathrm{Ar}$ distances of 2.57 and $2.75 \AA$, respectively.

We then investigated the ability of the enantiomeric hosts to discriminate stereoisomeric carbohydrates. ${ }^{1} \mathrm{H}$ NMR titration experiments between the two enantiomers of receptor 3 and six carbohydrates ( $\alpha$ - and $\beta$-mannose, $\alpha$ - and $\beta$-glucose, and $\alpha$ - and $\beta$-galactose, Figure 1) were thus performed in $\mathrm{CDCl}_{3}$ at $298 \mathrm{~K}$. In all cases, only one set of signals was observed for the complex and for the receptor, showing that the host-guest exchange is fast on the NMR time scale. As the aromatic protons of the CTV unit display sharp well-defined signals without overlap with other ones, their complexation-induced shifts were plotted as a function of the guest/host ratio (Figures S22-S27). In light of recent articles dealing with the stoichiometry of host/guest complexes and the determination of the related binding constants, titration curves were fitted with different models, i.e., stoichiometry, using the Bindfit program, instead of performing Job's plot experiments. ${ }^{18,19}$ In all cases, the better fit was obtained with a 1:1 host/guest stoichiometry, which is in agreement with the mass analysis of the (-)-3 and Oct- $\beta$-Glc mixture (Figure S20). From the resulting association constants reported in Table 1 , several features can be underlined. (i) First, good association constants up to $10^{3} \mathrm{M}^{-1}$ can be reached, in particular, for the binding of Oct- $\beta$-Glc by (-)-3. (ii) Second, the enantioselectivity remains high: an enantioselectivity of $96: 4$ is reached between (-)-3 and (+)-3 for the recognition of Oct- $\beta$-Glc, with binding constants of 993 and $45 \mathrm{M}^{-1}$, respectively. It is all the more remarkable that the enantioselectivity of the recognition process is only controlled by the inherent chirality of the CTV moiety. This is in sharp contrast with most of the previous hemicryptophane cages used to complex enantioselectively carbohydrates, which involved additional stereogenic units (center or axis). ${ }^{17}$ This enantioselectivity is even exclusive with galactose derivatives since no recognition occurs with the receptor (+)-3, whereas host (-)-3 displays binding constants of 245 and $274 \mathrm{M}^{-1}$ for the Oct- $\alpha$-Gal and Oct- $\beta$-Gal guests, respectively. (iii) Good $\alpha / \beta$ discrimination can be also achieved with these receptors: the binding constant is ten times higher for Oct- $\beta$-Glc than for Oct- $\alpha$-Glc with (-)-3 as a receptor (993and $100 \mathrm{M}^{-1}$, respectively), and 30 times higher for Oct- $\alpha$ -
Table 1. Binding Constants $K_{\mathrm{a}}\left(\mathrm{M}^{-1}\right)$ for the 1:1 Complexes Formed between the Different Isomers of Host 3 and the Carbohydrate Guests ${ }^{a}$

$\begin{array}{cccc}\text { guest } & \text { host } & K_{\mathrm{a}}\left(\mathrm{L} \mathrm{mol}^{-1}\right) & \text { enantioselectivity } \\ \text { Oct- } \beta \text {-Glc } & (-)-3 & 993 \pm 7.3 \% & 96: 4 \\ & (+)-3 & 45 \pm 3.1 \% & \\ \text { Oct- } \beta \text {-Gal } & (-)-3 & 274 \pm 3.2 \% & >99.5: 0.5 \\ & (+)-3 & b & \\ \text { Oct- } \beta \text {-Man } & (-)-3 & 7 \pm 2.3 \% & 1: 99 \\ & (+)-3 & 856 \pm 7.8 \% & \\ \text { Oct- } \alpha \text {-Glc } & (-)-3 & 100 \pm 3.2 \% & 77: 23 \\ & (+)-3 & 30 \pm 1.4 \% & \\ \text { Oct- } \alpha \text {-Gal } & (-)-3 & 245 \pm 4.7 \% & >99.5: 0.5 \\ & (+)-3 & b & \\ \text { Oct- } \alpha \text {-Man } & (-)-3 & 218 \pm 2.1 \% & 30: 70 \\ & (+)-3 & 508 \pm 5.2 \% & \end{array}$

${ }^{a} K_{\mathrm{a}}$ was determined by fitting ${ }^{1} \mathrm{H}$ NMR titration curves $\left(\mathrm{CDCl}_{3}, 500\right.$ $\mathrm{MHz}, 298 \mathrm{~K}$ ) on the aromatic protons of the CTV unit ( $\delta$ at $6.90 \mathrm{ppm}$ for the free host) with the Bindfit program. More details on the calculation results (covariance and RMS) can be found in Table S4; estimated error $=10 \% .{ }^{b}$ No complexation detected.

Man than for Oct- $\beta$-Man with (-)-3 as a receptor (218 and 7 $M^{-1}$, respectively). (iv) Whereas the (-)-3 enantiomer is Oct$\beta$-Glc-selective with a selectivity from moderate to high (a selectivity of 3.6:1 and 141:1 when compared to Oct- $\beta-$ Gal and Oct- $\beta$-Man, respectively), the (+)-3 enantiomer displays an Oct-Man selectivity, with a binding constant up to $856 \mathrm{M}^{-1}$, for Oct- $\beta$-Man and less than $45 \mathrm{M}^{-1}$ for other glucose and galactose derivatives. This change in substrate selectivity suggests different orientations and interactions of Oct- $\beta$-Glc and Oct-Man inside the cavities of (-)-3 and (+)-3, respectively. As the abilities of carbohydrates to induce intermolecular hydrogen bonds is the following: Oct- $\alpha$-Man $>$ Oct- $\beta$-Man $>$ Oct- $\beta$-Glc $>$ Oct- $\alpha$-Glc $>$ Oct- $\alpha$-Gal $\geq$ Oct- $\beta$ $\mathrm{Gal}^{20,21}$ and hydrogen bonds play probably a more important role in the formation of Oct- $\alpha-\operatorname{Man} @(+)-3$ than in the in the case of the Oct- $\beta$-Glc@(-)-3.

\section{CONCLUSIONS}

In summary, we have described the synthesis of a new chiral hemicryptophane cage. Its resolution has allowed the investigation of the stereoselective recognition properties of the two enantiomers toward six carbohydrate stereoisomers. In sharp contrast with other hemicryptophane derivatives, this new host combines both good binding constants (up to $10^{3}$ $\mathrm{M}^{-1}$ ) and remarkable enantioselectivity (exclusive in some cases). Moreover, depending on the enantiomer of the receptor used, a strong change in substrate selectivity is observed, allowing to choose the most appropriate hemicryptophane enantiomer to complex selectively the desired sugar derivative.

\section{EXPERIMENTAL SECTION}

Chemicals and Materials. Starting material and solvents were of commercial grade and were used without further purification. Chromatography was carried out with Merck 60 A (0.040-0.063 $\mathrm{mm}$ ) silica gel. TLC was performed with Merck silica gel 60 F254 plates. Melting points were determined with a Büchi Melting Point B545 unit. IR spectra were obtained using a Bruker Alpha Platinium ATR unit. ${ }^{1} \mathrm{H}$ NMR and ${ }^{13} \mathrm{C}$ NMR were recorded at $298 \mathrm{~K}$ on a Bruker Avance III HD $300 \mathrm{MHz}$ spectrometer and a Bruker Avance III HD $400 \mathrm{MHz}$ spectrometer. ${ }^{1} \mathrm{H}$ NMR and ${ }^{13} \mathrm{C}$ NMR chemical shifts $(\delta)$ are reported in ppm and referenced to the protonated residual 
solvent signal. HRMS were performed on a SYNAPT G2 HDMS (Waters) mass spectrometer with API, and spectra were obtained with TOF analysis. Measurements were realized with two internal standards. ECD spectra were recorded on a Jasco J-815 spectrometer in $\mathrm{CH}_{2} \mathrm{Cl}_{2}$.

CTV-Derivative 4. Compound 4 was prepared according to the published procedure. ${ }^{13}$

Synthesis of $5 .{ }^{22}$ In a dry $100 \mathrm{~mL}$ round-bottom flask, compound 4 $(1.30 \mathrm{~g}, 1.78 \mathrm{mmol})$ was dissolved in dry DMF $(40 \mathrm{~mL})$ and sodium azide $(1.16 \mathrm{~g}, 17.8 \mathrm{mmol})$ was added portionwise. The mixture was stirred at $60^{\circ} \mathrm{C}$ overnight. The solvent was partially removed under reduced pressure, and the resulting crude mixture was diluted with $\mathrm{CH}_{2} \mathrm{Cl}_{2}(50 \mathrm{~mL})$. Water was added $(50 \mathrm{~mL})$, and the layers were separated. The aqueous layer was extracted with $\mathrm{CH}_{2} \mathrm{Cl}_{2}(30 \mathrm{~mL})$. The organic layers were combined, washed with water $(3 \times 30 \mathrm{~mL})$, and dried over $\mathrm{MgSO}_{4}$. A yellowish oil was obtained after evaporation of the solvent under reduced pressure. Diethyl ether $(70 \mathrm{~mL})$ was added, and the mixture was stored at $4{ }^{\circ} \mathrm{C}$ for about $6 \mathrm{~h}$ to give a white solid, which was filtered on a frit and washed with $\mathrm{Et}_{2} \mathrm{O}$ to yield $5(990 \mathrm{mg}$, 90\%): ${ }^{1} \mathrm{H} \mathrm{NMR}\left(\mathrm{CDCl}_{3}, 300 \mathrm{MHz}, 298 \mathrm{~K}\right) \delta 6.93(\mathrm{~s}, 3 \mathrm{H}), 6.85(\mathrm{~s}$, $3 \mathrm{H}), 4.75(\mathrm{~d}, J=13.7 \mathrm{~Hz}, 3 \mathrm{H}), 4.14(\mathrm{t}, J=5.2 \mathrm{~Hz}, 6 \mathrm{H}), 3.83(\mathrm{~s}, 9 \mathrm{H})$, $3.59-3.52(\mathrm{~m}, 9 \mathrm{H}) ;{ }^{13} \mathrm{C} \mathrm{NMR}\left(\mathrm{CDCl}_{3}, 75 \mathrm{MHz}, 298 \mathrm{~K}\right) \delta 149.2$, $146.5,133.9,131.9,118.1,114.2,69.2,56.2,50.3$, 36.4; IR $\nu 2931$, 2110, 1511, $1265 \mathrm{~cm}^{-1}$; HRMS (ESI-TOF) $\mathrm{m} / z[\mathrm{M}+\mathrm{Na}]^{+}$calcd for $\mathrm{C}_{30} \mathrm{H}_{33} \mathrm{~N}_{9} \mathrm{O}_{6} \mathrm{Na}$ 638.2446, found 638.2442; $R_{f} 0.23\left(\mathrm{CH}_{2} \mathrm{Cl}_{2}\right) ; \mathrm{mp}$ $137-138{ }^{\circ} \mathrm{C}$.

Synthesis of 6. Compound 5 (490 mg, $0.796 \mathrm{mmol}$ ) was dissolved in THF $(15 \mathrm{~mL})$ and water $(0.5 \mathrm{~mL})$, and triphenylphosphine $(3.75 \mathrm{~g}$, $14.3 \mathrm{mmol}$ ) was slowly added at $0{ }^{\circ} \mathrm{C}$. The reaction mixture was stirred at $\mathrm{rt}$ for $16 \mathrm{~h}$, and the solvent was removed under reduced pressure. Diethyl ether $(50 \mathrm{~mL})$ was added to the resulting solid, and the mixture was stirred at $\mathrm{rt}$ for $24 \mathrm{~h}$. Filtration afforded compound 6 as a white powder $(391 \mathrm{mg}, 91 \%):{ }^{1} \mathrm{H}$ NMR $\left(\mathrm{CDCl}_{3}, 400 \mathrm{MHz}, 298\right.$ K) $\delta 6.88(\mathrm{~s}, 3 \mathrm{H}), 6.82(\mathrm{~s}, 3 \mathrm{H}), 4.75(\mathrm{~d}, J=13.7 \mathrm{~Hz}, 3 \mathrm{H}), 4.07-3.92$ $(\mathrm{m}, 6 \mathrm{H}), 3.82(\mathrm{~s}, 9 \mathrm{H}), 3.53(\mathrm{~d}, J=13.4 \mathrm{~Hz}, 3 \mathrm{H}), 3.05(\mathrm{t}, J=5.2 \mathrm{~Hz}$, $6 \mathrm{H}) ;{ }^{13} \mathrm{C}$ NMR $\left(\mathrm{CDCl}_{3}, 100 \mathrm{MHz}, 298 \mathrm{~K}\right) \delta 148.5,147.1,132.6$, 131.9, 116.1, 113.8, 72.0, 56.2, 41.6, 36.5; IR $\nu$ 3430, 2935, 1511, 1263 $\mathrm{cm}^{-1}$; HRMS (ESI-TOF) $\mathrm{m} / z[\mathrm{M}+\mathrm{H}]^{+}$calcd for $\mathrm{C}_{30} \mathrm{H}_{40} \mathrm{~N}_{3} \mathrm{O}_{6}$ 538.2912, found 538.2913; $R_{f} 0.05\left(\mathrm{CH}_{2} \mathrm{Cl}_{2} / \mathrm{MeOH} 97 / 3\right)$; mp 174$176^{\circ} \mathrm{C}$.

Synthesis of $7^{23}$ To a solution of salicylaldehyde $(158 \mu \mathrm{L}, 1.52$ $\mathrm{mmol})$ in absolute ethanol $(20 \mathrm{~mL})$ was added $\mathrm{NaOH}(66 \mathrm{mg}, 1.65$ $\mathrm{mmol})$. The reaction mixture was stirred at $\mathrm{rt}$ for $40 \mathrm{~min}$, and a solution of 1,3,5- tris(bromomethyl)benzene $(151 \mathrm{mg}, 0.423 \mathrm{mmol}$ ) in absolute ethanol $(7 \mathrm{~mL})$ was added. The mixture was refluxed for $20 \mathrm{~h}$ and cooled to $4{ }^{\circ} \mathrm{C}$ overnight. The resulting solid was filtered off and washed with cold ethanol and cold water to afford trialdehyde 7 as a white powder (165 mg, 78\%): ${ }^{1} \mathrm{H}$ NMR $\left(\mathrm{CDCl}_{3}, 300 \mathrm{MHz}, 298 \mathrm{~K}\right) \delta$ $10.53(\mathrm{~s}, 3 \mathrm{H}), 7.87(\mathrm{dd}, J=7.7,1.7 \mathrm{~Hz}, 3 \mathrm{H}), 7.58-7.52(\mathrm{~m}, 6 \mathrm{H}), 7.07$ $(\mathrm{dd}, J=17.2,8.1 \mathrm{~Hz}, 6 \mathrm{H}), 5.25(\mathrm{~s}, 6 \mathrm{H}) ;{ }^{13} \mathrm{C} \mathrm{NMR}\left(\mathrm{CDCl}_{3}, 75 \mathrm{MHz}\right.$, 298 K) $189.7,160.9,137.7,136.2,129.0,126.0,125.4,121.5,113.2$, 70.2; IR $\nu$ 3053, 2842, 1677, 1604, 1392, $1269 \mathrm{~cm}^{-1}$; HRMS (ESITOF) $m / z\left[\mathrm{M}+\mathrm{NH}_{4}\right]^{+}$calcd for $\mathrm{C}_{30} \mathrm{H}_{28} \mathrm{NO}_{6}$ 498.1911, found 498.1915; $R_{f} 0.32\left(\mathrm{CH}_{2} \mathrm{Cl}_{2}\right)$; mp $135-137{ }^{\circ} \mathrm{C}$.

Synthesis of Hemicryptophanes 3. To a solution of compound 6 $(179 \mathrm{mg}, 0.333 \mathrm{mmol})$ in a $1 / 1$ mixture of $\mathrm{CHCl}_{3} / \mathrm{MeOH}(120 \mathrm{~mL})$ was added dropwise a solution of trialdehyde $7(147 \mathrm{mg}, 0.306 \mathrm{mmol})$ in the same mixture of solvents $(80 \mathrm{~mL})$. The reaction mixture was stirred overnight at $\mathrm{rt}$, and $\mathrm{NaBH}_{4}(407 \mathrm{mg}, 10.7 \mathrm{mmol})$ was added portionwise at $0{ }^{\circ} \mathrm{C}$. The mixture was stirred at $\mathrm{rt}$ for $4 \mathrm{~h}$; solvents were removed under reduced pressure. The crude residue was dissolved in $\mathrm{CHCl}_{3}(60 \mathrm{~mL})$ and washed with a $10 \% \mathrm{NaOH}$ solution $(30 \mathrm{~mL})$. The aqueous phase was extracted with $\mathrm{CHCl}_{3}(2 \times 20 \mathrm{~mL})$, and combined organic layers were washed with a $10 \% \mathrm{NaOH}$ solution $(40 \mathrm{~mL})$ and dried over $\mathrm{MgSO}_{4}$. The organic solvent was removed under reduced pressure to afford a white solid, which was purified by column chromatography $\left(\mathrm{CHCl}_{3} / \mathrm{MeOH} / \mathrm{Et}_{3} \mathrm{~N}\right.$, gradient from $97 / 1 / 2$ to $90 / 8 / 2$ ). Racemic hemicryptophanes 3 were obtained as white solids (126 mg, 42\%).
The resolution of the racemic mixture was performed by chiral HPLC using a Chiralpak ID $(250 \mathrm{~mm} \times 10 \mathrm{~mm})$ column with EtOH and $\mathrm{Et}_{3} \mathrm{~N} / \mathrm{CH}_{2} \mathrm{Cl}_{2}(50 / 50)$ as the mobile phase (Supporting Information) to yield the two enantiopure hemicryptohanes (-)-3 $(30 \mathrm{mg}$, ee $>99.5 \%)$ and $(+)-3\left(34 \mathrm{mg}\right.$, ee > 98.5\%): ${ }^{1} \mathrm{H}$ NMR $\left(\mathrm{CDCl}_{3}, 400 \mathrm{MHz}, 298 \mathrm{~K}\right) \delta 7.21(\mathrm{dd}, J=7.3,1.6 \mathrm{~Hz}, 3 \mathrm{H}), 7.08(\mathrm{td}, J$ $=8.0,1.6 \mathrm{~Hz}, 3 \mathrm{H}), 6.97(\mathrm{~s}, 3 \mathrm{H}), 6.87(\mathrm{t}, J=7.1 \mathrm{~Hz}, 6 \mathrm{H}), 6.78(\mathrm{~s}, 3 \mathrm{H})$, $6.58(\mathrm{~d}, J=8.0 \mathrm{~Hz}, 3 \mathrm{H}), 4.73(\mathrm{~d}, J=13.7 \mathrm{~Hz}, 3 \mathrm{H}), 4.28-4.14(\mathrm{~m}$, $12 \mathrm{H}), 3.95(\mathrm{~d}, J=13.2 \mathrm{~Hz}, 3 \mathrm{H}), 3.88-3.81(\mathrm{~m}, 3 \mathrm{H}), 3.62(\mathrm{~s}, 9 \mathrm{H})$, $3.53(\mathrm{~d}, J=13.8 \mathrm{~Hz}, 3 \mathrm{H}), 3.49$ (br s, $3 \mathrm{H}), 3.13-3.05(\mathrm{~m}, 3 \mathrm{H}), 2.99-$ $2.92(\mathrm{~m}, 3 \mathrm{H}) ;{ }^{13} \mathrm{C} \mathrm{NMR}\left(\mathrm{CDCl}_{3}, 100 \mathrm{MHz}, 298 \mathrm{~K}\right) \delta 156.3,149.0$, $146.5,137.1,132.0,131.0,130.9,129.5,126.9,121.0,113.6,112.1$, 69.1, 68.6, 56.1, 48.8, 47.3, 36.4; IR v 3438, 2929, 1602, 1510, 1490, $1457,1263,1220 \mathrm{~cm}^{-1}$; HRMS (ESI-TOF) $\mathrm{m} / z[\mathrm{M}+\mathrm{H}]^{+}$calcd for $\mathrm{C}_{60} \mathrm{H}_{64} \mathrm{~N}_{3} \mathrm{O}_{9} 970.4637$, found 970.4639; $R_{f} 0.06\left(\mathrm{CHCl}_{3} / \mathrm{MeOH} / \mathrm{Et}_{3} \mathrm{~N}\right.$ $96 / 2 / 2) ; \mathrm{mp} \mathrm{299-302}{ }^{\circ} \mathrm{C} ; \mathrm{M}-(-)[\alpha]_{\mathrm{D}}^{25}-79\left(\mathrm{c} \mathrm{0.15}, \mathrm{CH}_{2} \mathrm{Cl}_{2}\right) ; P-(+)$ $[\alpha]_{\mathrm{D}}^{25}+78\left(c 0.235, \mathrm{CH}_{2} \mathrm{Cl}_{2}\right)$.

${ }^{1} \mathrm{H}$ NMR Titrations. A solution of enantiopure host $3(1.0 \mathrm{mM}$ in $\mathrm{CDCl}_{3}, 500 \mu \mathrm{L}$ ) was titrated in NMR tubes with aliquots of a concentrated solution (10 $\mathrm{mM}$ in the same solvent) of carbohydrates. The shifts $\Delta \delta$ of the host's protons signals at $6.90 \mathrm{ppm}$ were measured after each addition and plotted as a function of the guest/host ratio $([\mathrm{G}] /[\mathrm{H}])$. The association constant $K_{\mathrm{a}}$ was obtained by nonlinear least-squares fitting of these plots using the Bindfit program from Thordarson's group. ${ }^{19} K_{\mathrm{a}}$, covariance, and RMS are reported for each carbohydrate in the Supporting Information.

\section{REFERENCES}

(1) Wong, C.-H. Carbohydrate-Based Drug Discovery; Wiley-VCH: Weinheim, 2003.

(2) Roth, J. Chem. Rev. 2002, 102, 285-304.

(3) Angata, T.; Varki, A. Chem. Rev. 2002, 102, 439-470.

(4) Ernst, B.; Hart, G. W.; Sinaý, P. Carbohydrates in Chemistry and Biology; Wiley-VCH: Weinheim, 2000.

(5) Tohda, K.; Gratzl, M. ChemPhysChem 2003, 4, 155-161.

(6) For reviews, see: (a) Mazik, M. Chem. Soc. Rev. 2009, 38, 935956. (b) Davis, A. P. Org. Biomol. Chem. 2009, 7, 3629-3638.

(7) For more recent examples, see: (a) Francesconi, O.; Gentili, M.; Nativi, C.; Ardá, A.; Cañada, F. J.; Jiménez-Barbero, J.; Roelens, S. Chem. - Eur. J. 2014, 20, 6081-6091. (b) Chandramouli, N.; Ferrand, Y.; Lautrette, G.; Kauffmann, B.; Mackereth, C. D.; Laguerre, M.; Dubreuil, D.; Huc, I. Nat. Chem. 2015, 7, 334-341. (c) Mooibroek, T. J.; Casas-Solvas, J. M.; Harniman, R. L.; Renney, C. M.; Carter, T. S.; Crump, M. P.; Davis, A. P. Nat. Chem. 2016, 8, 69-74. (d) Mooibroek, T. J.; Crump, M. P.; Davis, A. P. Org. Biomol. Chem. 2016, 14, 19301933. (e) Lippe, J.; Seichter, W.; Mazik, M. Org. Biomol. Chem. 2015, 13, 11622-11632. (f) Amrhein, F.; Lippe, J.; Mazik, M. Org. Biomol. Chem. 2016, 14, 10648-10659. (g) Ríos, P.; Mooibroek, T. J.; Carter, T. S.; Williams, C.; Wilson, M. R.; Crump, M. P.; Davis, A. P. Chem. 
Sci. 2017, 8, 4056-4061. (h) Mandal, P. K.; Kauffmann, B.; Destecroix, H.; Ferrand, Y.; Davis, A. P.; Huc, I. Chem. Commun. 2016, 52, 9355-9358. (i) Gunasekara, R. W.; Zhao, Y. J. Am. Chem. Soc. 2017, 139, 829-835. (j) Yabushita, M.; Li, P.; Bernales, V.; Kobayashi, H.; Fukuoka, A.; Gagliardi, L.; Farha, O. K.; Katz, A. Chem. Commun. 2016, 52, 7094-7097. (k) Hwang, J. Y.; Jeon, H.-G.; Choi, Y. R.; Kim, J.; Kang, P.; Lee, S.; Jeong, K.-S. Org. Lett. 2017, 19, 56255628.

(8) (a) Hardie, M. J. Chem. Soc. Rev. 2010, 39, 516-527. (b) Lefevre, S.; Heloin, A.; Pitrat, D.; Mulatier, J.-C.; Vanthuyne, N.; Jean, M.; Dutasta, J.-P.; Guy, L.; Martinez, A. J. Org. Chem. 2016, 81, 31993205.

(9) Lefevre, S.; Simonet, R.; Pitrat, D.; Mulatier, J.-C.; Vanthuyne, N.; Jean, M.; Dutasta, J.-P.; Guy, L.; Martinez, A. ChemistrySelect 2016, 1, 6316-6320.

(10) Zhang, D.; Martinez, A.; Dutasta, J.-P. Chem. Rev. 2017, 117, 4900-4942.

(11) Schmitt, A.; Chatelet, B.; Padula, D.; Bari, L. D.; Dutasta, J.-P.; Martinez, A. New J. Chem. 2015, 39, 1749-1753.

(12) Perraud, O.; Martinez, A.; Dutasta, J.-P. Chem. Commun. 2011, 47, 5861-5863.

(13) Chatelet, B.; Payet, E.; Perraud, O.; Dimitrov-Raytchev, P.; Chapellet, L.-L.; Dufaud, V.; Martinez, A.; Dutasta, J.-P. Org. Lett. 2011, 13, 3706-3709.

(14) (a) Canceill, J.; Collet, A.; Gabard, J.; Gottarelli, G.; Spada, G. P. J. Am. Chem. Soc. 1985, 107, 1299-1308. (b) Canceill, J.; Collet, A.; Gottarelli, G.; Palmieri, P. J. Am. Chem. Soc. 1987, 109, 6454-6464.

(15) Ardá, A.; Venturi, C.; Nativi, C.; Francesconi, O.; Cañada, F. J.; Jiménez-Barbero, J.; Roelens, S. Eur. J. Org. Chem. 2010, 75, 64-71.

(16) Francesconi, O.; Gentili, M.; Roelens, S. J. Org. Chem. 2012, 77, $7548-7554$.

(17) Zhang, D.; Mulatier, J.-C.; Cochrane, J. R.; Guy, L.; Gao, G.; Dutasta, J.-P.; Martinez, A. Chem. - Eur. J. 2016, 22, 8038-8042.

(18) Ulatowski, F.; Dąbrowa, K.; Bałakier, T.; Jurczak, J. J. Org. Chem. 2016, 81, 1746-1756.

(19) Hibbert, D. B.; Thordarson, P. Chem. Commun. 2016, 52, 12792-12805.

(20) Bonar-Law, R. P.; Sanders, J. K. M. J. Am. Chem. Soc. 1995, 117, 259-271.

(21) López de la Paz, M.; Ellis, G.; Pérez, M.; Perkins, J.; JiménezBarbero, J.; Vicent, C. Eur. J. Org. Chem. 2002, 2002, 840-855.

(22) Wang, L.; Wang, G.-T.; Zhao, X.; Jiang, X.-K.; Li, Z.-T. J. Org. Chem. 2011, 76, 3531-3535.

(23) Le Gac, S.; Zeng, X.; Girardot, C.; Jabin, I. J. Org. Chem. 2006, $71,9233-9236$. 